\title{
Ontogenesis of LH and FSH receptors in postnatal rabbit testes: age-dependent differential expression of long and short RNA transcripts
}

\author{
P. Laborde ${ }^{1}$, R. J. Barkey ${ }^{2}$, L. Belair ${ }^{3}$, J.J. Remy ${ }^{1}$, J. Djiane ${ }^{3}$ and \\ R. Salesse ${ }^{1 *}$ \\ ${ }^{1}$ Unité Récepteurs et Communication Cellulaire, INRA-Biotechnologies, 78352-Jouy-en-Josas Cédex, France; \\ ${ }^{2}$ Department of Pharmacology, the Rappaport Faculty of Medicine, Technion, POB 9649, Haifa, 31096, \\ Israel; and 'Unité d'Endocrinologie Moléculaire, INRA-Biotechnologies, 78352-Jouy-en-Josas Cédex, France
}

\begin{abstract}
The ontogeny of testicular LH and FSH receptors was studied in New Zealand rabbits from 20 to 180 days postpartum. The concentrations of free receptors (per $\mathrm{mg}$ total proteins) were very low at day 20 . They increased steeply at day 30 for the $\mathrm{LH}$ receptor and at day 50 for the FSH receptor. Three RNA bands (1.2, 2.5 and $3 \mathrm{~kb})$ were repeatedly detected on northern blots for the LH receptor and two bands ( 1.2 and $2.2 \mathrm{~kb}$ ) were detected for the FSH receptor. The $1.2 \mathrm{~kb}$ band (which cannot give rise to full-length, membrane-anchored receptor) was present throughout the 20-180 day period for each receptor. However, the higher molecular mass bands were nearly undetectable at day 20 . The 2.5 and $3 \mathrm{~kb}$ bands of the LH receptor increased twofold between day 20 and day 120 , while the $2.2 \mathrm{~kb}$ band of the FSH receptor increased fivefold between day 20 and day 75 . Thus the very low concentrations, or even absence, of the larger transcripts of both LH and FSH receptors were correlated with the inability to detect their cognate protein until 20 days of age. Subsequently, coordinated increases in high molecular mass transcripts and protein were observed for both receptors. Total $\mathrm{LH}$ receptor content increased in parallel to the previously reported increase in plasma testosterone between day 65 and day 100. FSH receptor density began to increase steeply at day 50, just at the onset of spermatogenesis. Thus, postnatal testicular development in the rabbit seems to entail the transcription of high molecular mass, translatable transcripts of the gonadotrophin receptors.
\end{abstract}

\section{Introduction}

Rabbit testes undergo both morphological and functional changes at the onset of puberty, starting at around 45 days of age with the first gonal mitosis. Between 42 and 140 days, the mass of the testis increases from $0.5 \mathrm{~g}$ to about $6 \mathrm{~g}$. At day $50-60$, the onset of spermatogenesis is indicated by the appearance of spermatogonia A and B. Shortly thereafter, plasma concentrations of testosterone increase steeply from day 65 until day 100, when the first spermatids appear (reviewed in Boussit, 1989). This suggests that during this period of sexual development, somatic cells (particularly Leydig and Sertoli cells) involved in testis physiology increase their number and metabolism.

Since the activity of these cells is largely controlled by gonadotrophins (that is, Leydig cells by LH and Sertoli cells by FSH), it was considered useful to study the expression of the gonadotrophin receptors during this period. Thus, the testicular content of LH and FSH receptors was evaluated by radioreceptor assay and the size and abundance of their mRNAs

*Correspondence.

Received 30 October 1995. were analysed by northern blotting in rabbits between 20 and 180 days of age.

\section{Materials and Methods}

\section{Animals}

New Zealand male rabbits (10-24 of each age group) were reared at INRA local facilities in Jouy-en-Josas. Animals were killed; testes were dissected out, snap frozen in liquid nitrogen and then stored at $-80^{\circ} \mathrm{C}$. Testis mass, with tunica albuginea, but devoid of annexes (epididymis, tunica vaginalis) was measured before freezing and was about $25 \mathrm{mg}$ at day 20 , $65 \mathrm{mg}$ at day $30,200 \mathrm{mg}$ at day $50,310 \mathrm{mg}$ at day 75 , $1700 \mathrm{mg}$ at day 122 and $2100 \mathrm{mg}$ at day 150.

\section{Receptor assays}

Concentrations of free receptors were determined in testicular homogenates (Goxe et al., 1993). Briefly, 0.5-1 g of frozen testes (or pieces thereof) were reduced to powder at $-80^{\circ} \mathrm{C}$, 
and then thawed in $1-3 \mathrm{ml}$ of homogenization buffer $(10 \mathrm{mmol}$ Tris- $\mathrm{HCl} \mathrm{l}{ }^{-1}, \mathrm{pH} \mathrm{7.4,3.8} \mathrm{mmol} \mathrm{NaCl} \mathrm{l}^{-1}, 3 \mathrm{mmol} \mathrm{KCl} \mathrm{l}^{-1}$, $1 \mathrm{mmol}$ phenyl-methyl sulfonyl fluoride (PMSF) $\mathrm{I}^{-1}, 1 \mathrm{mmol}$ benzamidine $\mathrm{I}^{-1}$ and $\left.0.04 \%(\mathrm{w} / \mathrm{v}) \mathrm{NaN}_{3}\right)$ and homogenized at $4^{\circ} \mathrm{C}$ in a mortar with three strokes of a teflon pestle. Lumps were decanted and supernatant collected for receptor assay and protein measurement (BCA kit from Pierce, Roissy, based on the spectrometric measurement of the complexes between bicinchoninic acid and $\mathrm{Cu}^{2+}$ ions as reduced by peptide bonds).

Purified hCG (batch CR127, NIH, Bethesda, MD) was labelled with ${ }^{125} \mathrm{I}$ using Iodogen (Pierce) as catalyst (Genty et al., 1987). The labelled hormone was purified on a Sephadex G-25 column (Pharmacia, St-Quentin-en-Yvelines) and the specific activity of the resulting tracer was 800-1500 $\mathrm{Ci} \mathrm{mmol}^{-1}$. ${ }^{125}$ I-labelled human FSH (Christophe et al., 1993) was a gift from P. Robert (Faculté de Pharmacie, Paris). Crude commercial preparations of hCG (Chorulon; Intervet, Angers) and pig FSH (a gift from $Y$. Combarnous, INRA, Tours) were used for the determination at nonspecific binding.

Binding was determined at three dilutions (equivalent to 4 , 12 and $35 \mathrm{mg}$ of tissue) in $100 \mu \mathrm{l}$ of homogenization buffer and compared with a standard binding curve made with similar dilutions of a known pig testis homogenate, and normalized per $\mathrm{mg}$ protein. Total binding was determined in the presence of 40-100 nmol of ${ }^{125}$ I-labelled hormone $\mathrm{I}^{-1}$, and nonspecific binding in the presence of a 500-1000-fold excess of unlabelled commercial hormone preparation. After $16 \mathrm{~h}$ at $20^{\circ} \mathrm{C}$, the incubations were stopped by dilution with $1.6 \mathrm{ml}$ of ice-cold

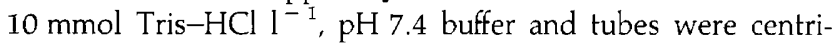
fuged at $3500 \mathrm{~g}$ at $4^{\circ} \mathrm{C}$ for $12 \mathrm{~min}$. The supernatant was aspirated and the radioactivity of the pellet was determined using a LKB gamma counter (Pharmacia). The difference between total and nonspecific binding was taken as specific binding. Results were calculated as the means \pm SEM of triplicate determinations.

\section{RNA characterization}

Total RNA was isolated according to Chomczynski and Sacchi (1987), as modified by Puissant and Houdebine (1990). About $100 \mathrm{mg}$ of testis were homogenized in $1 \mathrm{ml}$ of $4.2 \mathrm{~mol}$ guanidinium thiocyanate $1^{-1}$ (GuSCN, Fluka, L'Isle d'Abeau) solution containing $25 \mathrm{mmol}$ sodium citrate $1^{-1}, 0.5 \%(\mathrm{w} / \mathrm{v})$ $n$-lauryl-sarcosine and $0.1 \mathrm{~mol} \beta$-mercaptoethanol $\mathrm{l}^{-1}$. To this mixture, $0.1 \mathrm{vol}$ of 2 mol sodium acetate $\mathrm{l}^{-1}, \mathrm{pH} 4$ was added and a first extraction with 1 vol phenol (water-saturated) and $0.2 \mathrm{vol}$ chloroform (chloroform: iso-amyl alcohol, 49:1) was performed. The mixture was placed on ice for $15 \mathrm{~min}$, centrifuged for $30 \mathrm{~min}$ at $3000 \mathrm{~g}$ and RNAs in the aqueous phase were precipitated overnight at $-20^{\circ} \mathrm{C}$ by the addition of $1 \mathrm{vol}$ isopropanol. The RNA pellet was recovered by centrifugation $\left(30 \mathrm{~min}, 3000 \mathrm{~g}, 4^{\circ} \mathrm{C}\right.$ ), rinsed with $70 \%$ ethanol, and dissolved in sterile water. RNAs were precipitated by the addition of $4-5 \mathrm{vol}$ of $4 \mathrm{~mol} \mathrm{LiCl} l^{-1}$ at $4^{\circ} \mathrm{C}$ for $2 \mathrm{~h}$. The RNA was pelleted as above and redissolved in a minimum volume of sterile water. A last extraction with 1 vol of chloroform-isoamyl alcohol was performed. After $15 \mathrm{~min}$ on ice, the aqueous phase was recovered by centrifugation $(3000 \mathrm{~g}, 20 \mathrm{~min})$. RNA was precipitated overnight with 0.1 vol of sodium acetate (final concentration of $0.2 \mathrm{~mol} \mathrm{l}^{-1}$ ) and $2.5 \mathrm{vol}$ ethanol and pelleted $\left(30 \mathrm{~min}, 10000 \mathrm{~g}, 4^{\circ} \mathrm{C}\right)$. After washing with $70 \%$ ethanol, RNAs were dissolved and quantified by absorbance measurements at $260 \mathrm{~nm}$ and $280 \mathrm{~nm}$ (absorbance ratio about two) and checked by agarose gel electrophoresis. Aliquots of 20 and $40 \mu \mathrm{g}$ were stored in $70 \%$ ethanol, $0.2 \mathrm{~mol}$ sodium acetate $1^{-1}$ at $-20^{\circ} \mathrm{C}$.

Northern blot analysis was performed after electrophoresis on a $1.66 \%$ agarose gel in electrophoresis buffer $(20 \mathrm{mmol}$ $\mathrm{NaH}_{2} \mathrm{PO}_{4} \mathrm{I}^{-1}, \mathrm{pH} 7,5 \mathrm{mmol}$ sodium acetate $\mathrm{I}^{-1}, 1 \mathrm{mmol}$ EDTA $\mathrm{l}^{-1}, 2.2 \mathrm{~mol}$ formaldehyde $\mathrm{l}^{-1}$ ). Twenty $\mu \mathrm{g}$ of each RNA was denatured $\left(10 \mathrm{~min}, 65^{\circ} \mathrm{C}\right)$ in $10 \mu \mathrm{l}$ denaturation buffer (electrophoresis buffer supplemented with $45 \%(\mathrm{v} / \mathrm{v})$ formamide, $15 \%(\mathrm{v} / \mathrm{v})$ formaldehyde), cooled at $0^{\circ} \mathrm{C}$, and supplemented with $10 \mu \mathrm{l}$ of $20 \%(\mathrm{w} / \mathrm{v})$ Ficoll, $2 \mathrm{mmol}$ EDTA $\mathrm{I}^{-1}, 0.2 \%(\mathrm{w} / \mathrm{v})$ bromophenol blue. After migration, the gel was washed successively with sterile water and $10 \times$ SSC (1.5 mol $\mathrm{NaCl} \mathrm{l}^{-1}, 0.15 \mathrm{~m}$ sodium citrate $\mathrm{l}^{-1}, \mathrm{pH}$ 7) and transferred overnight to Zeta Probe membrane (Biorad, Ivry-sur-Seine). After rinsing, filters were fixed for $2 \mathrm{~min}$ under UV irradiation.

Filters were then pre-hybridized for $3 \mathrm{~h}$ at $65^{\circ} \mathrm{C}$ in $0.5 \mathrm{~mol}$ sodium phosphate $1^{-1}, \mathrm{pH} 7.2,7 \%(\mathrm{w} / \mathrm{v})$ sodium dodecyl sulfate solution containing $5 \mathrm{~g}$ skimmed milk powder $\mathrm{l}^{-1}$ and

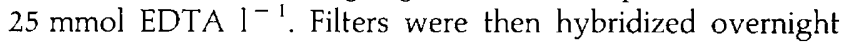
under the same conditions with the full-length cDNA probes for pig LH receptor (Loosfelt et al., 1989) and pig FSH receptor (Remy et al., 1995). Each probe was labelled by random priming with the Amersham Multiprime kit using $\left[\alpha-{ }^{32} \mathrm{P}\right] \mathrm{dCTP}$ $\left(3000 \mathrm{Ci} \mathrm{mmol}^{-\mathrm{I}}\right)$ for $3 \mathrm{~h}$ at room temperature to specific activities of approximately $10^{9}$ c.p.m. $\mu \mathrm{g}^{-1}$. The filters were submitted to autoradiography (Kodak X-Omat S films, with intensifying screen) and band densities measured with the Pharmacia Image Master system and normalized to $1 \mathrm{mg}$ total RNA. $\beta$-Actin probe (Alonso et al., 1986) was not used for correction because its hybridization between days 30 and 75 was five times more intense than at day 20 and after day 120 . Instead, ethidium bromide staining of ribosomal RNAs was used to check equal loading of electrophoresis tracks. Results were calculated as the means \pm SEM of triplicate or quadruplicate determinations.

\section{Results}

\section{Expression of $L H$ and $F S H$ receptors}

The expression of $\mathrm{LH}$ and FSH receptors with postnatal age is displayed (Fig. 1). Receptors were detected with difficulty at day 10 (not shown). The amount of each receptor as c.p.m. tracer bound per mg protein was very low at day 20 and increased sharply at day 30 for the LH receptor (Fig. 1a) and at day 50 for the FSH receptor (Fig. Ib); noticeably, testis descent occurred around day 50. After day 75, binding concentrations declined slightly. When the total amount of receptors was estimated as pmol per testis, the increase was especially noticeable after day 75 , which parallels the onset of testosterone production observed in previous studies (Boussit, 1989). 

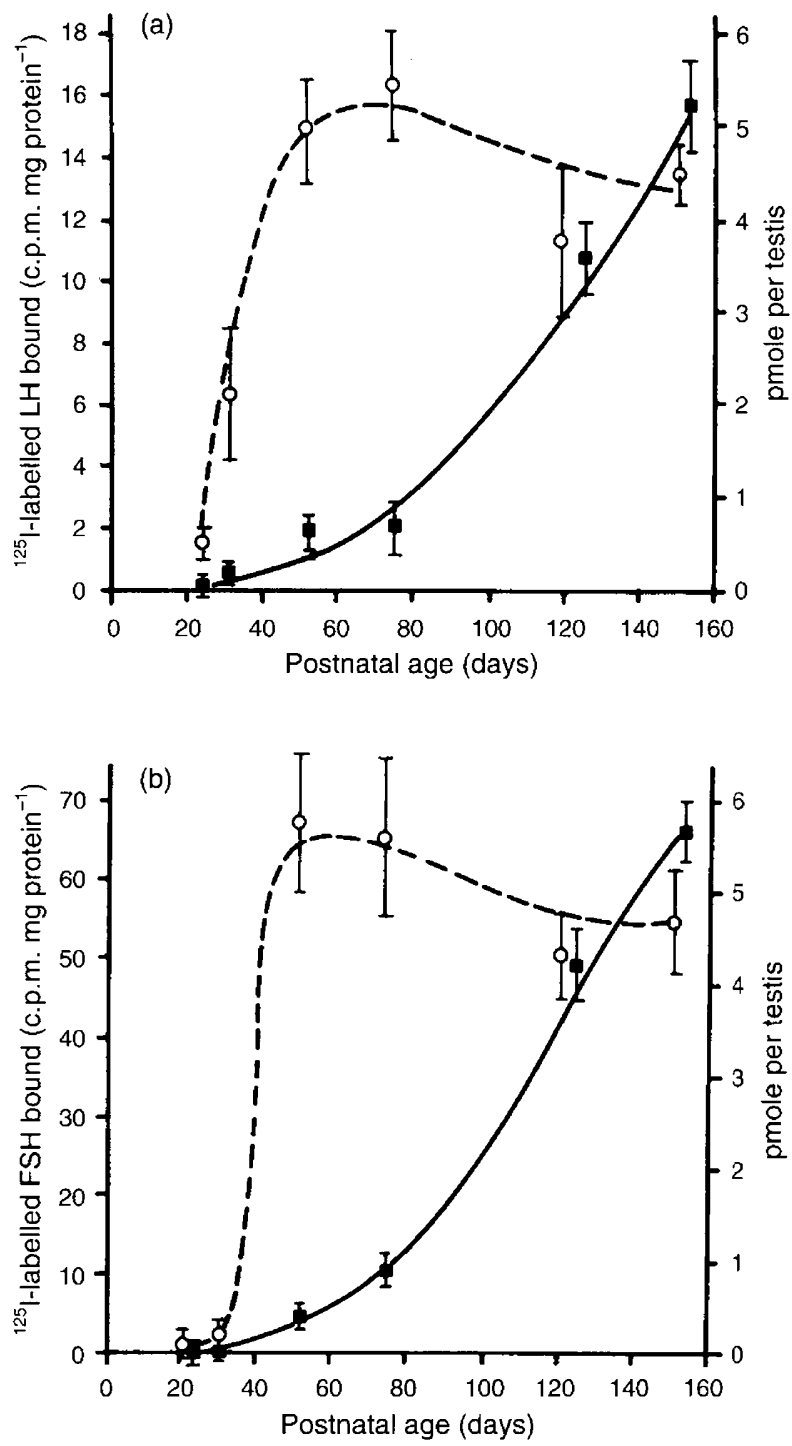

Fig. 1. Expression of gonadotrophin receptors in rabbit testes during postnatal development. Free receptors were measured in testis homogenates with ${ }^{125}$ I-labelled (a) LH or (b) FSH. Specific binding was calculated as (o) c.p.m. mg protein ${ }^{-1}$ or ( $\mathbf{m}$ ) pmoles per testis. Results were calculated as the means \pm SEM of triplicate determinations.

\section{Northern blots analysis}

The age-dependent changes in the pattern of receptor RNAs encoding LH and FSH as detected by northern blots are shown (Fig. 2), and the absorbances of the main hybridization bands after densitometry are also given (Fig. 3). Adult (180 days) testis revealed four bands for the $\mathrm{LH}$ receptor probe $(1.2,2.5,3$ and $4.2 \mathrm{~kb}$ ). However, the intensity of the $4.2 \mathrm{~kb}$ band was faint in some animals, independent of age; thus it was not used for quantification. Two bands at 1.2 and $2.2 \mathrm{~kb}$ were found for the FSH receptor (Fig. 2b). When earlier developmental stages were studied, the intensities of the low molecular mass bands $(1.2 \mathrm{~kb})$ normalized to $1 \mathrm{mg}$ total RNAs were only slightly lower than in the adult (Fig. 3), except at day 20 for the FSH receptor. However, the high molecular mass bands of both receptors were significantly less intense than their adult (a)

kb

4.2

3.0

2.5

1.2

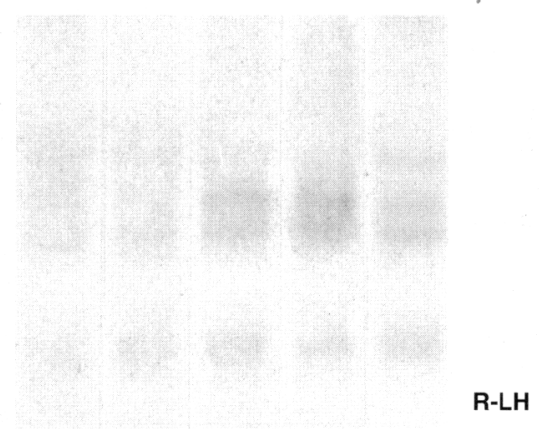

rib.

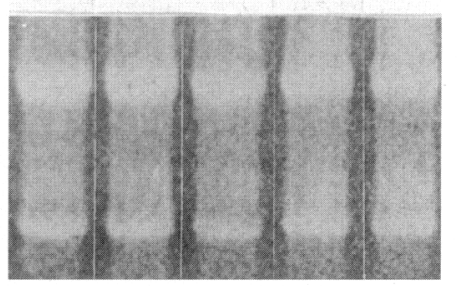

(b)

kb

R-FSH

rib.

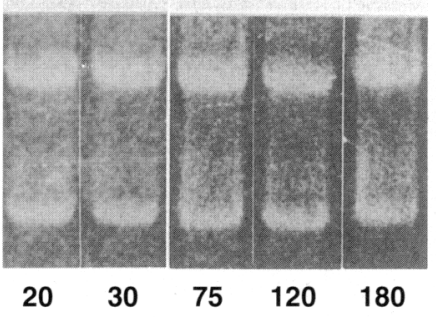

Fig. 2. Northern blots of RNAs encoding gonadotrophin receptors from rabbit testes during postnatal development. Total RNA was extracted from individual rabbit testes of the indicated age (days) and $20 \mu \mathrm{g}$ were run on agarose gel and transferred before hybridization with (a) cDNA probe for the pig LH receptor (R-LH) or (b) cDNA probe for pig FSH receptor (R-FSH). For each figure: upper part, northern blot; lower part, ethidium bromide staining of ribosomal RNAs $28 \mathrm{~s}$ and $18 \mathrm{~s}$ (rib.). The figure is representative of one set of RNAs. Note that autoradiographic exposure was carried out for 10 days ( $\mathrm{LH}$ receptor) and 3 days (FSH receptor). 

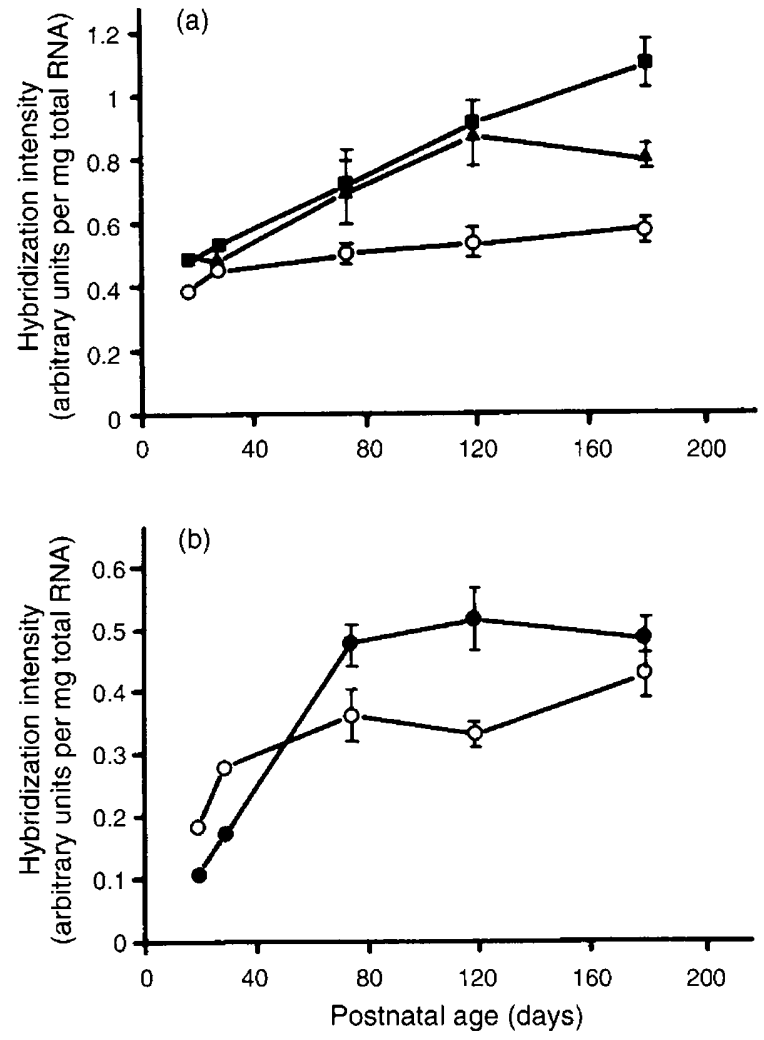

Fig. 3. Changes in the relative intensities of the hybridization bands of the gonadotrophin receptors in rabbit testes with postnatal age. The intensities of the bands detected by northern blot in Fig. 2 were plotted versus postnatal age of the rabbits for (a) the $\mathrm{LH}$ receptor and (b) the FSH receptor. Absorbances were normalized per $1 \mathrm{mg}$ total RNA. (@) $2.5 \mathrm{~kb},(\bullet) 3 \mathrm{~kb},(0) 1.2 \mathrm{~kb},(\bullet) 1.2 \mathrm{~kb}$. Each sample was run in triplicate or quadruplicate and values shown are means \pm SEM of arbitrary units.

counterparts: at days 20 and 30 , the intensity of the $\mathrm{LH}$ receptor was $50 \%$ of that at day 180 (Fig. 3a), whereas intensity of the $2.2 \mathrm{~kb}$ band of the FSH receptor was only $20-25 \%$ of that at day 180 (Fig. 3 b). These results indicate that the relative content in high molecular mass RNAs increased with the stage of development for both receptors, especially after 30 days of age, in parallel with the protein itself. The best correlation was found between the acquisition of the FSH receptor and the intensity of its $2.2 \mathrm{~kb}$ RNA. For the $\mathrm{LH}$ receptor, the increase in relative receptor amount occurred as early as day 30 , while the amount of RNA hybridization was only slightly higher than at day 20 .

\section{Discussion}

The expression of $\mathrm{LH}$ and FSH receptors in the testis has been correlated consistently with activity and/or development of their cognate tissues in various mammalian species. During fetal ontogenesis, expression of receptors occurs soon after sexual differentiation in pigs (Goxe et al., 1993) and rats (Warren et al., 1984; Rannikki et al., 1995). Between stages VII-VIII and XIII-II of spermatogenesis, the concentration of RNAs encoding the FSH receptor in the rat seminiferous epithelium underwent a threefold increase (Heckert and Griswold, 1991). The neonatal rabbit testis exhibits a slowdown of growth around day 20-24 followed by a wave of development (Allen, 1904). Thus, it was not surprising to find that during early (days 30-50) prepubertal development of the rabbit testis, the expression of both receptors per mg protein increased, and that their increase was accompanied by previously described physiological events: onset of spermatogenesis (days 45-60) and testosterone secretion (after day 60). Furthermore, the whole testis content in both receptors rose steadily, indicating a continuous development of both Leydig and Sertoli cells with gain in testicular mass. Such a correlation with testicular growth has already been reported in pigs (Peyrat et al., 1981; Goxe et al., 1993).

Previous work has demonstrated the existence of a number of transcripts (ranging from $1.2 \mathrm{~kb}$ up to $7.5 \mathrm{~kb}$ ) in the gonads of all mammalian species studied for the LH receptor: pigs (Loosfelt et al., 1989), rats (McFarland et al., 1989), humans (Minegish et al., 1990), and mice (Gudermann et al., 1992); and for the FSH receptor: rats (Sprengel et al., 1990), humans (Minegish et al., 1991), sheep (Yarney et al., 1993), monkeys (Gromoll et al., 1993), horses (Robert et al., 1994), and cattle (Houde et al., 1994). Since the minimal expected coding length is $2.1 \mathrm{~kb}$, those transcripts of shorter length are considered as noncoding or potentially encoding for truncated forms of the receptors, representing the extracellular, possibly soluble, domain of the receptor (Segaloff and Ascoli, 1993). Alternatively, truncated forms of the receptor may be attributed to proteolysis (Kellokumpu and Rajaniemi, 1985; West and Cooke, 1991) rather than to translation of short transcripts. In any case, soluble forms of the receptor would not be detected in the particulate fractions used in our study. The absence (or very low amount) of hormone binding was correlated with the presence of only a short transcript $(1.2 \mathrm{~kb})$ and with a low amount or absence of high molecular mass RNA. This situation is well illustrated by the FSH receptor, for which even the increase of the sole $1.2 \mathrm{~kb}$ RNA between days 20 and 30 is accompanied by a persistent absence of FSH binding. For the LH receptor, this holds true at day 20 , while at day 30 the protein seems to be overexpressed as compared with the small amounts of 2.5 and $3 \mathrm{~kb}$ RNAs. Nevertheless, situations have already been described where the protein:RNA ratio of the $\mathrm{LH}$ receptors change as a result of physiological events such as lactation in rabbit does (Kermabon et al., 1994) or subsequent to in vitro hormonal stimulation of cultured pig granulosa cells (Goxe et al., 1992). In the latter system, mRNAs encoding the FSH receptor have also been reported to increase in the face of decreased hormone binding (Sites et al., 1994).

The expression of the higher molecular mass transcripts of the rat LH receptor has been correlated with expression of the receptor itself, both at the onset of ovarian development (Sokka et al., 1992) and upon maturation of testicular Leydig cells (Zhang et al., 1994). Similar findings have been reported for the FSH receptor in rat gonads (Rannikki et al., 1995). The origin of the variety of gonadotrophin receptor transcripts may be primarily attributed to heterogeneity in the length of their $3^{\prime}$ untranslated regions. Three sites of transcription termination, separated by about $2 \mathrm{~kb}$ from one another, have been found in the rat gene ( $\mathrm{Hu}$ et al., 1994). It may be that, in rabbits, 
termination could take place at one proximal site for the $\mathrm{LH}$ and FSH receptors ( 2.5 and $2.2 \mathrm{~kb}$ bands, respectively) and at two additional distal sites for the $\mathrm{LH}$ receptor ( 3 and $4.2 \mathrm{~kb}$ bands). The potency of the $4.2 \mathrm{~kb}$ terminator could be lower than that of the $3 \mathrm{~kb}$ terminator, giving rise to some irregularities in the intensity of the corresponding band. In addition, transcript diversity may also derive from extensive alternative splicing of the pre-messenger RNAs (Aatsinki et al., 1992; Bacich et al., 1994) and from exon skipping (Koo et al., 1994). Thus, $1.2 \mathrm{~kb}$ mRNAs, essentially devoid of the region coding for the transmembrane domain of the $\mathrm{LH}$ receptor, could arise from splicing between the $5^{\prime}$ end of the tenth exon and $3^{\prime}$ acceptor sites within the 11th exon (Loosfelt et al., 1989; Bernard et al., 1990; Koo et al., 1994). Similar truncated mRNAs of the FSH receptor have also been reported (Gromoll et al., 1992).

The low abundance of the larger transcripts in the early postnatal gonad may also be attributed to their reduced lifespan. This suggestion is in keeping with previous results indicating that the smaller transcripts would always be present in the gonads, even immature gonads (Aatsinki et al., 1992; Rannikki et al., 1995) or results obtained after downregulation induced by high doses of hCG (Wang et al., 1991; Hsueh and LaPolt, 1992; Lakkakorpi et al., 1993; Chuzel et al., 1995). Indeed, hCG did not affect the rate of transcription of the LH receptor gene, but reduced the stability of its larger mRNAs (Lu et al., 1993). The decrease in mRNA lifespan could be attributed to short-lived proteins whose translation is inhibited by cycloheximide (Goxe and Salesse, 1993; Shi and Segaloff, 1995).

Another molecular mechanism accounting for the presence of short transcripts may be premature termination of transcription. Indeed, one hypothesis concerning transcription termination of polyintronic genes suggests that, beyond the last exon, sequences typical of $3^{\prime}$-untranslated region, such as polyadenylation sequences (AAUAAA or similar), would be recognized by the polymerase II complex (Proudfoot, 1989; Manley, 1995). Such sequences are found in introns 3,4 and 10 of the rat $\mathrm{LH}$ receptor genes, where transcripts are stopped after the $3 \mathrm{rd}$, 4th and 10th exons (Koo et al., 1994). This could also be the case in the immature rabbit testis before day 30. Subsequently, the transcriptional and post-transcriptional machinery of the testis would reach a functional level ailowing completion of transcription, correct splicing and stabilization of RNAs, although still leaving significant amounts of truncated transcripts. The rabbit testis thus appears to provide a suitable model for study of regulatory mechanisms (possibly hormonal) involved in the generation of translatable mRNAs of the gonadotrophin receptors since, unlike in the testes of other mammalian species, only a limited number of bands were identified by northern blotting, thus offering an advantage for the study of the generation, lifespan and role of the short transcripts.

For the kind gift of purified hormones, the authors thank NIDDK, National Hormone and Pituitary Program (Baltimore, MD), Y. Combarnous (INRA, Tours), P. Robert (Faculté de Pharmacie, Paris). They thank M. Baratte, I. Boulay and R. Allais for providing rabbits. This work was supported in part by grants from Institut National de la Recherche Agronomique, from Ministère de l'Education Nationale et de l'Enseignement Supérieur et de la Recherche, from Naturalia et Biologia and from Fondation Dufrenoy.

\section{References}

Aatsinki JT, Pietilä EM, Lakkakorpi JT and Rajaniemi HJ (1992) Expression of the LH/CG receptor gene in rat ovarian tissue is regulated by an extensive alternative splicing of the primary transcript Molecular and Cellular Endocrinology 84 127-135

Allen, BM (1904) The embryonic development of the ovary and testis of the mammals American Journal of Anatomy 3 89-153

Alonso S, Minty A, Bourlet Y and Buckingham M (1986) Comparison of three actin-coding sequences in the mouse; evolutionary relationships between the actin genes of warm-blooded vertebrates Journal of Molecular Evolution 23 $11-22$

Bacich DJ, Rohan RM, Norman RJ and Rodgers RJ (1994) Characterization and relative abundance of alternatively spliced luteinizing hormone receptor messenger ribonucleic acid in the ovine ovary Endocrinology 135 735-744

Bernard MP, Myers RV and Moyle WR (1990) Cloning of rat lutropin (LH) receptor analogs lacking the soybean lectin domain Molecular and Cell Endocrinolology 71 r19-r23

Boussit D (1989) Physiologie du lapin mâle. In Reproduction et Insémination Artificielle en Cuniculture, pp. 27-43 Eds Association Française de Cuniculture, Lempdes, France

Chomczynski P and Sacchi N (1987) Single-step method of RNA isolation by acid guanidinium thiocyanate-phenol-chloroform extraction Analytical Biochemistry 162 156-159

Christophe S, Robert P, Maugain S, Bellet DH, Koman A and Bidart JM (1993) Expression of the human follicle-stimulating hormone receptor in the Baculovirus system Biochemical and Biophysical Research Communications 193 402-408

Chuzel F, Schteingart HF, Vigier M, Avallet O and Saez JM (1995) Transcriptional and post-transcriptional regulation of luteotropin/chorionic gonadotrophin receptor by the agonist in Leydig cells European Journal of Biochemistry 229 316-325

Genty N, Salesse R and Garnier J (1987) Internalization and recycling of lutropin receptors upon stimulation by porcine lutropin and human choriogonadotrophin in porcine Leydig cells Biology of the Cell 59 129-136

Goxe B, Salesse R, Remy JJ, Genty N and Garnier J (1992) LH receptor RNA and protein levels after hormonal treatment of porcine granulosa cells in primary culture Journal of Molecular Endocrinology 8 119-129

Goxe B and Salesse R (1993) Involvement of short-lived proteins in the regulation of expression of the $\mathrm{LH}$ receptor Reproduction Nutrition Developpement 33 84-85

Goxe B, Prunier A, Remy JJ and Salesse R (1993) Ontogeny of gonadal luteinizing hormone and follicle-stimulating hormone receptors in the fetal pig and related changes in gonadotrophin and testosterone secretion Biology of Reproduction 49 609-616

Gromoll J, Gudermann T and Nieschlag E (1992) Molecular cloning of a truncated isoform of the human follicle stimulating hormone receptor Biochemical and Biophysical Research Communications 188 1077-1083

Gromoll J, Dankbar B, Shyam Sharman R and Nieschlag E (1993) Molecular cloning of the testicular follicle stimulating hormone receptor of the non human primate Macaca fascicularis and identification of multiple transcripts in the testis Biochemical and Biophysical Research Communications 196 1066-1072

Gudermann T, Birnbaumer $M$ and Birnbaumer L (1992) Evidence for dual coupling of the murine luteinizing hormone receptor to adenylyl cyclase and phosphoinositide breakdown and $\mathrm{Ca}^{2+}$ mobilization. Studies with the cloned murine luteinizing hormone receptor expressed in $\mathrm{L}$ cells Journal of Biological Chemistry 267 4479-4488

Heckert LL and Griswokd MD (1991) Expression of follicle-stimulating hormone receptor mRNA in rat testes and Sertoli cells Molecular Endocrinology $5670-677$

Houde A, Lambert A, Saumande J, Silversides DW and Lussier JG (1994) Structure of the bovine follicle-stimulating hormone receptor complementary DNA and expression in bovine tissues Molecular Reproduction and Development 39 $127-135$

Hsueh AJW and LaPolt PS (1992) Molecular basis of gonadotrophin receptor regulation Trends in Endocrinology and Metabolism 3 164-170

Hu ZZ, Buczko E, Zhuang L and Dufau ML (1994) Sequence of the $3^{\prime}$-noncoding region of the luteinizing hormone receptor gene and identification of two polyadenylation domains that generate the major mRNA forms Biochimica et Biophysica Acta $\mathbf{1 2 2 0} 333-337$ 
Kellokumpu S and Rajaniemi HJ (1985) Hormone binding modifies endogenous proteolysis of LH/hCG receptors in rat ovarian plasma membranes Molecular and Cellular Endocrinology 42 157-162

Kermabon AY, Belair L, Theau-Clément M, Salesse R and Djiane J (1994) Effects of anoestrus and bromocryptine treatment on the expression of prolactin and LH receptors in the rabbit ovary during lactation Joumal of Reproduction and Fertility 102 131-138

Koo YB, Ji I and Ji TH (1994) Characterization of different sizes of rat luteinizing hormone/chorionic gonadotrophin receptor messenger ribonucleic acids Endocrinology 134 19-26

Lakkakorpi JT, Pietilä EM, Aatsinki JT and Rajaniemi HJ (1993) Human chorionic gonadotrophin (CG)-induced down-regulation of the rat luteal LH/CG receptor results in part from the down-regulation of its synthesis, involving increased alternative processing of the primary transcript Journal of Molecular Endocrinology 10 153-162

Loosfelt H, Misrahi M, Atger M, Salesse R, VuHaï-Luu Thi MT, Jolivet A, Guiochon-Mantel A, Sar S, Jallal B, Garnier J and Milgrom E (1989) Cloning and sequencing of porcine LH-hCG receptor CDNA: variants lacking transmembrane domain Science 245 525-528

Lu DL, Peegel H, Mosier SM and Menon KMJ (1993) Loss of lutropin/human choriogonadotrophin receptor messenger ribonucleic acid during ligandinduced down-regulation occurs post transcriptionally Endocrinology 132 235-240

McFarland KC, Sprengel R, Phillips HS, Köhler M, Rosemblit N, Nikolics K, Segaloff DL and Seeburg PH (1989) Lutropin-choriogonadotrophin receptor: an ususual member of the $G$ protein-coupled receptor family Science $\mathbf{2 4 5}$ 494-499

Manley JL (1995) A complex protein assembly catalyzes polyadenylation of mRNA precursors Current Biology 5 222-228

Minegish T, Nakamura K, Takakura $Y$, Miyamoto $K$, Hasegawa $Y$, Ibuki $Y$ and Igarashi M (1990) Cloning and sequencing of human LH/hCG receptor DNA Biochemical and Biophysical Research Communications 172 1049-1054

Minegish T, Nakamura K, Takakura Y, Ibuki Y and Igarashi M (1991) Cloning and sequencing of human FSH receptor cDNA Biochemical and Biophysical Research Communications 175 1125-1130

Peyrat JP, Meusy-Dessolle N and Garnier J (1981) Changes in Leydig cells and luteinizing hormone receptors in porcine testis during postnatal development Endocrinology 108 625-631

Proudfoot NJ (1989) How RNA polymerase II terminates transcription in higher eukaryotes Trends in Biochemical Sciences 14 105-110

Puissant C and Houdebine LM (1990) An improvement of the single-step method of RNA isolation by acid guanidinium thiocyanate-phenolchloroform extraction BioTechniques 8 148-149
Rannikki AS, Zhang FP and Huhtaniemi IT (1995) Ontogeny of follicle stimulating hormone receptor gene expression in the rat testis and ovary Molecular and Cellular Endocrinology 107 199-208

Remy JJ, Lahbib-Mansais Y, Yerle M, Bozon V,Couture L, Pajot-Augy E, Grebert D and Salesse R (1995) The porcine follitropin receptor: cDNA cloning, functional expression and chromosomal localization of the gene Gene 163 257-261

Robert P, Amsellem S, Christophe S, Benifla JL, Bellet DH, Koman A and Bidart JM (1994) Cloning and sequencing of the equine testicular follitropin receptor Biochemical and Biophysical Research Communications 201 201-207

Segaloff DL and Ascoli M (1993) The lutropin/choriogonadotrophin receptor .. 4 years later Endocrine Reviews 14 324-344

Shi $\mathrm{H}$ and Segaloff DL (1995) A role for increased lutropin/ choriogonadotrophin receptor (LHR) gene transcription in the follitropin-stimulated induction of the LHR in granulosa cells Molecular Endocrinology 9 734-744

Sites CK, Patterson K, Jamison CS, Friezner Degen SJ. and La Barbera AR (1994) Follicle-stimulating hormone (FSH) increases FSH receptor messenger ribonucleic acid while decreasing FSH binding in cultured porcine granulosa cells Endocrinology 134 411-417

Sokka T, Hämäläinen TM and Huhtaniemi IT (1992) Functional LH receptor appears in the neonatal rat ovary after changes in the alternative splicing pattern of the LH receptor mRNA Endocrinology 130 1738-1740

Sprengel R, Braun T, Nikolics K, Segaloff DL and Seeburg PH (1990) The testicular receptor for follicle stimulating hormone: structure and functional expression of cloned cDNA Molecular Endocrinology 4 525-530

Wang H, Segaloff DL and Ascoli M (1991) Lutropin/choriogonadotropin downregulates its receptor by both receptor-mediated endocytosis and a cAMPdependent reduction in receptor mRNA Journal of Biological Chemistry 266 780-785

Warren DW, Huhtaniemi IT, Tapanainen JS, Dufau ML and Catt KJ (1984) Ontogeny of gonadotrophin receptors in the fetal and neonatal rat testis Endocrinology 114 470-476

West AP and Cooke BA (1991) Regulation of the truncation of luteinizing hormone receptors at the plasma membrane is different in rat and mouse Leydig cells Endocrinology 128 363-370

Yarney TA, Sairam MR, Khan H, Ravindranath N, Payne GS and Seidah NG (1993) Molecular cloning and expression of the ovine testicular follicle stimulating hormone receptor Molecular and Cellular Endocrinology 93 219-226

Zhang FP, Hämäläinen TM, Kaipia A, Pakarinen P and Huhtaniemi IT (1994) Ontogeny of luteinizing hormone receptor gene expression in the rat testis Endocrinology $134 \quad 2206-2213$ 